\title{
Peran Keluarga Dalam Penanganan Anak dengan Penyakit ISPA Di RSUD Piru
}

\author{
Dary $^{1}$, Dhanang Puspita ${ }^{2}$, Jolanda Fretty Luhukay ${ }^{1}$ \\ Program Studi IImu Keperawatan, Fakultas Kedokteran dan Ilmu Kesehatan, Universitas Kristen Satya Wacana \\ Program Studi Teknologi Pangan, Fakultas Kedokteran dan Ilmu Kesehatan, \\ Universitas Kristen Satya Wacana
}

INF

Korespondensi

dary@staff.uksw.edu

Keywords:

ARI, role of family, toddler
Acute respiratory infection (ARI) is an acute infection disease that involves the respiratory organs. The number of ARI cases in RSUD Piru in 2015 were around 122 patients in the classification of outpatients. In 2016, ARI patients increased to 165 patients with the classification that 21 were inpatients and 144 were outpatients. Whereas in 2017, the number of ARI patients increased to 244 patients with a classification that all were outpatients. This research was aimed at elaborating the family role in treating ARI toddler-patients. The method used in this research was qualitative with phenomenology approach. The technique used to collect the data was through a deep interview. Research participants for this study were determined by the researcher (purposive sampling). The participants in this study were 10 parents who have toddlers (1-5 year-old children) with ARI. ARI contains three themes, they are: (1) family knowledge, (2) family role, (3) the prevention of ARI contagion. Conclusion: The family role in treating childrenpatients of ARI was through traditional treatment. If the traditional treatment did not work, then they brought their toddlers to the hospital to get the medicine from medics.

\begin{abstract}
Abstrak
Infeksi Saluran Pernafasan Akut (ISPA) adalah penyakit infeksi akut yang melibatkan organ saluran pernapasan. Angka kejadian ISPA di RSUD Piru pada tahun 2015 sebanyak 122 orang dengan klasifikasi semua pasien rawat jalan, pada 2016 penderita penyakit ISPA meningkat menjadi 165 orang dengan klasifikasi 21 penderita yang di rawat di Rumah Sakit dan 144 penderita rawat jalan. Sedangkan pada tahun 2017 penderita ISPA meningkat menjadi 244 orang, dengan klasifikasi semua pasien rawat jalan. Penelitian ini bertujuan untuk menguraikan peran keluarga dalam penanganan anak dengan ISPA. Metode penelitian yang digunakan dalam penelitian ini adalah kualitatif dengan pendekatan fenomenologi. Teknik pengumpulan data dengan cara wawancara mendalam. Partisipan penelitian ditentukan sesuai dengan karakteristik yang sudah ditentukan oleh peneliti, (purposive sampling). Partisipan dalam penelitian ini adalah 10 orang yang memiliki anak usia balita ( $1-5$ Tahun) dengan penyakit ISPA. Hasil penelitian terhadap partisipan mengenai peran keluarga dalam penanganan anak dengan penyakit ISPA meliputi tiga tema yaitu: (1) pengetahuan keluarga, (2) peran keluarga, (3) pencegahan penularan ISPA. Kesimpulan: Peran keluarga yang dilakukan dalam penanganan anak dengan ISPA dengan cara pengobatan tradisional. jika pengobatan tradisional tidak membuahkan hasil barulah keluarga akan membawa balitanya berobat ke RS untuk mendapatkan obat dari tenaga kesehatan.
\end{abstract}

Kata kunci: balita, ISPA, peran keluarga 
Pendahuluan

Infeksi Saluran Pernafasan Akut (ISPA) adalah penyakit infeksi akut yang melibatkan organ saluran pernapasan. Saluran nafas yang dimaksud adalah organ mulai dari hidung sampai alveoli paru (Intan, 2014). ISPA disebabkan oleh virus, jamur dan bakteri Staphylococcus, Streptococcus. Staphylococcus dan Streptococcus merupakan bakteri gram positif. Staphylococcus tumbuh pada lingkungan dengan temperatur 15 $45^{\circ} \mathrm{C}$, sedangkan Streptococcus tumbuh pada lingkungan dengan temperatur suhu $37^{\circ} \mathrm{C}$. Timbulnya gejala ISPA biasanya cepat, yaitu dalam waktu beberapa jam sampai beberapa hari. Gejalanya meliputi demam, batuk, dan sering juga nyeri tenggorokan, pilek, sesak napas, mengi, atau kesulitan bernapas (WHO, 2007).

Saat ini ISPA masih menjadi masalah kesehatan dunia. Menurut World Health Organization (2007) ISPA adalah penyebab utama morbiditas dan mortalitas penyakit menular di dunia, hampir 4 juta orang meninggal di dunia akibat ISPA setiap tahun (WHO, 2007). Tingkat mortalitas ISPA sangat tinggi pada bayi, anakanak, dan orang lanjut usia, terutama di negara-negara dengan pendapatan perkapita rendah dan menengah (Aries, 2015). Di Indonesia kasus ISPA berdasarkan diagnosis tenaga kesehatan dan keluhan penduduk adalah 25,0\%. Empat provinsi dengan ISPA tertinggi adalah Nusa Tenggara Timur, Papua, Nusa Tenggara Barat, dan Jawa Timur (Riskesdas, 2013).

Di Maluku angka kejadian ISPA meningkat. Menurut profil kesehatan provinsi Maluku (2014), penyakit dengan angka kejadian tertinggi adalah ISPA, dari tahun 2012 angka kejadian ISPA berada pada posisi pertama dengan jumlah 15.443 kasus, terjadi peningkatan pada tahun 2013 sebanyak 21.537 kasus, dan tahun 2014 angka kejadian menjadi 145.782 kasus (Profil kesehatan Provinsi maluku, 2014). ISPA sampai saat ini masih merupakan penyakit menular infeksi yang menyebabkan kematian balita. Rendahnya kualitas lingkungan pemukiman, serta pengetahuan masyarakat tentang kesehatan yang kurang, menyebabkan penyakit ini masih menjadi ancaman yang berbahaya bagi balita. Tingginya insiden penyakit ini tidak terlepas dari faktor penularan yang mudah terjadi dan faktor sosioekonomi masyarakat (Profil Kesehatan 
Kota Ambon, 2014). Angka kejadian ISPA di RSUD Piru pada tahun 2015 sebanyak 122 orang dengan klasifikasi semua pasien rawat jalan, pada 2016 penderita penyakit ISPA meningkat menjadi 165 orang dengan klasifikasi 21 yang di rawat di RS dan 144 menjalani rawat jalan. Sedangkan pada tahun 2017 penderita ISPA semakin meningkat menjadi 244 orang, dengan klasifikasi semua pasien rawat jalan.

Balita merupakan individu yang masih berada pada masa tumbuh kembang. Sistem imun pada usia ini masih relatif rendah dibandingkan dengan usia-usia selanjutnya. Sistem imun yang belum sempurna pada balita menyebabkan balita rentan terkena infeksi, yang salah satunya adalah ISPA. Pencegahan ISPA sangat erat kaitannya dengan sistem kekebalan tubuh yang dimiliki oleh seseorang. ISPA sangat rentan kepada balita, itulah mengapa kasus ISPA sebagai penyakit dengan prevalensi sangat tinggi di dunia juga menunjukkan angka kematian anak yang sangat tinggi dibandingkan penyakit lainnya. Orang tua memiliki peran yang penting dalam masa pertumbuhan anak, sekaligus dalam proses pencegahan dan penanggulangan penyakit ISPA. Peran orang tua antara lain adalah : peran sebagai penyedia, perawatan anak, sosialisasi anak, peran pendidikan, dan peran afektif. Alasan mengapa orang tua memegang peranan penting bagi kesehatan anak karena kehidupan seorang anak ditentukan oleh lingkungan keluarga (Stela, 2016).

Penanganan yang dilakukan masing-masing orang tua berbeda. Menurut penelitian yang dilakukan Florentina (2013), keterlambatan pencarian layanan kesehatan merupakan salah satu penyebab tingginya kematian akibat ISPA. Faktor-faktor yang dapat memengaruhi perilaku pencarian pelayanan kesehatan antara lain status sosial ekonomi, usia ibu, pendidikan ibu, persepsi orang tua, usia anak, jenis kelamin anak, jumlah balita dalam keluarga. Berdasarkan wawancara yang dilakukan oleh peneliti, sebagian orang tua yang sadar akan kesehatan anak, lebih memilih untuk membawa anak ke Rumah Sakit, namun ada juga orang tua yang membawa ke Puskesmas dan juga orang tua yang tidak terlalu memerhatikan kesehatan anak, dan dibiarkan saja. Berbeda dengan penelitian yang dilakukan Cipto (2015) peran keluarga dalam pencegahan anak dengan penyakit ISPA, berkaitan dengan tingkat pengetahuan orang tua, 
semakin rendah tingkat pengetahuan orang tua semakin tinggi resiko anak dengan penyakit ISPA, karena kurang adanya perhatian orang tua terhadap kebersihan anak. Berbeda dengan cara pencegahan orang tua di Ambon, orang tua menggosok minyak kayu putih ke badan anak, memberikan perasan jeruk nipis dicampur kecap, atau memberikan minyak campuran pala, cengkih yang sudah diracik untuk diminum karena dapat dipercaya mampu meredakan rasa sakit karena batuk yang dirasakan anak, namun ada juga orang tua yang membawa anaknya untuk diurut karena dipercaya kondisi anak akan lebih membaik dari sebelumnya.

Penelitian ini bertujuan untuk menguraikan bagaimana peran yang dilakukan keluarga dalam penanganan anak dengan penyakit ISPA di Ambon.

\section{Metode}

Penelitian ini menggunakan tipe penelitian kualitatif dengan pendekatan fenomenologi. Teknik pengumpulan data dengan wawancara mendalam yang disajikan secara deskripsi. Partisipan penelitian ditentukan sesuai dengan karakteristik yang sudah ditentukan oleh peneliti, (purposive sampling). Partisipan dalam penelitian ini adalah orang tua yang memiliki anak usia balita (1 -5 Tahun) dengan penyakit ISPA. Analisa data menggunakan model Miles dan Huberman. Analisa data model Miles dan Huberman terdiri dari tiga tahap, yang pertama Reduksi data, yang kedua Penyajian data, yang ketiga kesimpulan. Penelitian ini di lakukan di RSUD Piru, pada tanggal $16-30$ April 2017.

\section{Hasil dan Pembahasan}

\section{Hasil}

Penelitian dilaksanakan pada Bulan Mei 2017 yang bertempat di rumah partisipan. Partisipan yang diteliti adalah orang tua yang memiliki anak dengan penyakit ISPA, berjumlah 10 orang, 1 diantaranya berjenis kelamin laki-laki dengan klasifikasi umur, orang tua yang memiliki anak usia 2 tahun 1 orang, 3 tahun 2 orang, 4 tahun 3 orang, 5 tahun 4 orang. Hasil wawancara kepada partisipan mengenai peran keluarga dalam penanganan anak dengan penyakit ISPA meliputi tiga tema yaitu: (1) pengetahuan keluarga, (2) peran keluarga, (3) mencegah penularan 


\section{Pengetahuan keluarga}

Pengetahuan keluarga mengenai ISPA ialah dari 10 keluarga, 7 keluarga menganggap bahwa penyakit ISPA merupakan penyakit batuk biasa yang terjadi karena perubahan cuaca. Sedangkan 3 keluarga yang lain menganggap ISPA adalah penyakit karena adanya gangguan di saluran pernapasan seperti yang dikatakan dokter.

Berikut kutipan hasil wawancara pada keluarga:

"Yang saya tahu anak saya ini sakit batuk, sampe bikin dia kaya mau sesak napas bagitu ade" (Q3P3A1).

"Kurang tau lai ade, yang saya tahu anak saya ini sakit batuk karena cuaca yang tidak menentu seperti penyakit musiman begitu ade. Deng dia jua sering bermain di tanah-tanah, abu$a b u ” .(\mathrm{Q} 3 \mathrm{P} 2 \mathrm{~A} 1)$

"ade nona usi jua seng tau lai kata ISPA ini penyakit apa, yang usi tau Cuma ade ini sakit karena cuaca yang tidak stabil, soalnya disini tuh kadang panas, panas sekali, kadang juga hujan, tambah makan es-es jadi usi kira dia sakit karena itu" (Q4P6A1).
Ciri-ciri penyakit ISPA yang diketahui keluarga adalah batuk yang tidak sembuh, nyeri tenggorokan, dan membuat balita sesak napas. Semua partisipan mengatakan ciri-ciri yang sama. Seperti kutipan berikut:

"ciri-cirinya tuh, "beta anak ni babatu seng sembuh-sembuh, tenggorokan saki, baru tambah akang biking kaya mau hosa bagitu ade" (Q4P3A2).

("Ciri-cinya adalah "anak saya mengalami batuk yang tidak kunjung sembuh, tenggorokan sakit, sampai sesak nafas.")

"ciri-cirinya tuh, "beta anak ni babatu seng sembuh-sembuh, tenggorokan saki, baru tambah akang biking kaya mau hosa bagitu dek" (batuk-batuk tidak sembuh, tenggorokan sakit,sampai sesak napas). Soalnya kalau dong bermain tu ade seng pastiu hujan atau panas, dong barmaen saja, namanya jua anak-anak”. (Q4P4A2)

Penyebab ISPA yang partisipan ketahui disini adalah karena cuaca yang tidak teratur, anak sering mengkonsumsi makanan ringan/jajan, dan sering berdekatan dengan anggota keluarga yang merokok. 
Seperti kutipan berikut:

"suami saya seorang perokok aktif ade, dan suami saya ketika merokok tidak di luar rumah ade jadi asapnya langsung ke anak-anak namanya juga anak-anak jadi kalo su barmaen deng dong bapa dong barmaeng saja ade nona, terus cuaca yang tidak menentu, ketiga karena anak saya lebih sering mengkonsumsi makanan ringan, dan minuman dingin seperti fruitamin" (Q1P1A1).

("suami saya seorang perokok aktif, dan suami saya ketika merokok tidak di luar rumah jadi asapnya langsung ke anak-anak namanya juga anak-anak jadi kalau sudah bermain bersama bapaknya mereka akan bermain saja, terus cuaca yang tidak menentu, ketiga karena anak saya lebih sering mengkonsumsi makanan ringan, dan minuman dingin seperti fruitamin" (Q1P1A1).

\section{Peran keluarga pada Penderita ISPA}

Pengobatan sendiri merupakan penanganan yang pertama kali dilakukan partisipan bila ada balitanya yang tiba-tiba sakit dengan pengobatan tradisional, jika pengobatan sendiri tidak membuahkan hasil barulah keluarga berobat ke RS.
- Seperti pernyataan partisipan berikut ini:

"Saat itu yang bisa saya lakukan untuk sementara saya memberikan air hangat untuk diminum, setelah selesai mandi saya juga rutin menggosokan minyak kayu putih di badan anak saya ade, trus usi bawa dia ka tukang urut karena usi rasa mungkin karena dia terlalu sering barmaen jadi badanbadan sakit yang bikin dia sampe babatu" (Q1P6A2)

Alasan partisipan melakukan tindakan pengobatan sendiri karena pengalaman keluarga, dan juga biaya yang dikeluarkan tidak terlalu banyak.

Berikut peryataan partisipan:

"karena tindakan pengobatan tradisional merupakan tindakan yang turun-temurun dan saya juga merasakan hal yang sama" (Q9P9A9)

"saya juga memikirkan biaya untuk pulang balik dari rumah ke rumah sakit" (Q9P10A2).

Tindakan selanjutnya yang dilakukan apabila pengobatan tradisional tidak mengalami perubahan yaitu dengan membawa balita untuk diperiksa di RS atau puskesmas Berikut peryataan partisipan. 
"Belum sepenuhnya berhasil ade, karena anak saya masih batuk sampai mau sesak napas, terus saya bawa ke Rumah Sakit untuk mendapatkan obat "(Q1P4A3)

“ Belum berhasil ade, karena anak saya masih batuk sampai mau sesak napas, terus saya bawa lagi ke Rumah Sakit untuk mendapatkan obat, tetapi karena biaya jadi tidak bisa untuk rawat inap, jadi rawat jalan saja" (Q1P3A3)

Ada beberapa perlakuan khusus yang diberikan keluarga kepada balita yang menderita ISPA.

Berikut peryataan partisipan :

"Saya lebih memperhatikan kebersihan diri anak, anak saya, sering, menggosokan minyak kayu putih setelah selesai mandi. Itu saja perlakuan khusus yang saya berikan kepada anak saya" (Q6P4A2)

“ Saya lebih memperhatikan kebersihan anak saya, sering membatasi ade agar tidak terlalu bermain, tidak boleh terlalu makan es, memperhatikan jam makan anak" (Q6P7A2)
" lebih memperhatikan anak, kadangkadang memberikan perasan jeruk nipis dicampur kecap, memberikan air hangat untuk diminum, menggosokan minyak kayu putih setelah selesai topu badan. Itu saja perlakuan khusus yang saya berikan kepada anak saya". (Q6P2A2)

Harapan keluarga agar anak cepat sembuh, dan bisa beraktifitas seperti biasanya. Berikut peryataan partisipan :

"Harapan saya sebagai orang tua agar anak saya cepat sembuh dan bisa sehat seperti anak-anak yang lain." (Q10P10A1)

“ Harapan saya sebagai orang tua agar anak saya cepat sembuh dan bisa bermain seperti teman-teman yang lain, dan bisa menjadi anak yang berguna" (Q10P7A1)

\section{Pencegahan Penderita ISPA}

Cara pencegahan yang dilakukan keluarga juga hanya dengan membatasi aktifitas balita yang terserang ISPA dari anggota keluarga yang lain, dengan alasan anaknya masih terlalu kecil, jadi tidak ada cara lain untuk mencegah agar tidak terjadi penularan kepada anggota keluarga yang lain. 
Berikut peryataan partisipan :

"Iya ade, jadi anak saya ini kan masih kecil tidak ada banyak tindakan yang bisa saya lakukan untuk mencegah agar tidak terjadi penularan ke anggota keluarga yang lain. Yang bisa saya lakukan membatasi saja aktifitasnya dengan anggota keluarga yang lain. Karena dia masih kecil juga saya takut nanti malah membuat dia merasa berbeda" (Q8P2A1).

Keluarga tidak mendapatkan informasi dari orang lain mengenai cara pencegahan ISPA agar tidak terjadi penularan, langsung membatasi aktifitas anaknya. Dari 10 partisipan 6 partisipan mengatakan hal yang sama. Berikut peryataan partisipan :

"tidak mendapatkan informasi tentang cara pencegahan dari orang lain. Saya sendiri yang langsung melakukan tindakan”. (Q8P2A3)

“ Iya ade nona, usi jua kurang tau lai mau bikin bagaimana supaya seng terjadi penularan di anggota keluarga yang lain, yang usi tau, usi Cuma jaga membatasi dia, dari dia ade, nona, soalnya dia ade masi kacil taku jang sampe akang tajangke (menular) pa dia ade to nona. Soalnya ade ni masih kacil jadi seng bisa terlalu mau larang-larang dia lai ”. (Q8P6A1)

\section{Pembahasan}

\section{Pengetahuan tentang ISPA}

Pengetahuan merupakan faktor yang penting dalam membentuk tindakan seseorang (over behavior) (Paramitha, 2013). Pengetahuan merupakan hasil dari tahu dan ini terjadi setelah orang melakukan penginderaan terhadap suatu objek tertentu (Notoatmodjo 2010). Pengetahuan partisipan tentang penyakit ISPA pada balita bahwa penyakit ISPA adalah penyakit batuk, flu, dan demam biasa, yang disebabkan karena kondisi cuaca yang sering berganti-ganti, misalnya pergantian dari musim panas ke musim hujan, atau karena musim panas yang terlalu berlebihan dan terlalu banyak bermain di luar rumah, yang menyebabkan anak mereka menderita penyakit ISPA. Mereka menganggap penyakit ISPA adalah penyakit yang tidak membahayakan anak mereka. Mereka menganggap penyakit ISPA adalah penyakit batuk biasa yang sering terjadi pada anak-anak. Berdasarkan jawaban partisipan dapat disimpulkan bahwa 
partisipan masih belum memahami tentang penyakit ISPA

Secara klinis penyakit ISPA adalah penyakit yang disebabkan oleh virus atau infeksi gabungan virusbakteri, tetapi dianggap hanya penyakit biasa yang sering timbul dan tidak berbahaya serta bisa menghilang dengan sendirinya. Mayarakat masih kurang mendapatkan informasi kesehatan terkhususnya mengenai penyakit ISPA, sehingga partisipan kurang memahami tentang pola hidup bersih dan sehat, ada beberapa partisipan yang suaminya sering merokok di dalam rumah dan asapnya langsung dihirup oleh anak. Asap rokok dapat mengganggu saluran pernapasan termasuk ISPA. Menurut Prabu dkk dalam Wijaya (2014) asap rokok dapat merusak mekanisme pertahanan paru sehingga akan memudahkan terjadinya ISPA.

Partisipan juga kura memerhatikan nutrisi anak sal satunya makanan yang dikonsun oleh anak. Dari 10 responden, ada responden yang mengatakan bah' anaknya yang sedang sakit seri mengkonsumsi jajan dan es. Nutr anak yang baik dapat membantu an dalam proses penyembuhan. Menu penelitian yang dilakukan oleh Eva (2013) status gizi pada anak sangat penting, karena status gizi yang baik akan meningkatkan daya tahan tubuh dan kekebalan tubuh anak, sehingga anak tidak mudah terkena penyakit infeksi. Semakin rendah status gizi balita maka semakin rendah pula daya tahan tubuh balita, maka semakin rentan balita untuk terinfeksi. Partisipan juga kurang memahami mengenai gejala penyakit ISPA, secara umum partisipan mengatakan gejala penyakit ISPA hanya batuk, flu, seperti halnya ketika anak hanya sakit flu dan batuk biasa. Menurut WHO (2007) gejala ISPA meliputi demam, batuk, dan sering juga nyeri tenggorokan, pilek, sesak napas, mengi, atau kesulitan bernapas.

\section{Peran keluarga pada Penderita ISPA}

Peran keluarga merupakan tindakan nyata yang harus dilakukan oleh keluarga dalam merawat anggota keluarga terutama dalam mencegah ISPA pada balita karena balita merupakan kelompok yang rentan tertular penyakit (Ali, 2010). Peran orang tua merupakan penanganan yang dilakukan oleh ibu ataupun anggota keluarga yang lain. Keluarga 
merupakan unit terkecil dari penanganan awal yang dilakukan masyarakat yang berkumpul dan keluarga sebelum membawa anak ke tinggal dalam suatu rumah tangga, satu dengan yang lainnya saling bergantung dan berinteraksi, bila salah satu atau beberapa anggota keluarga yang mempunyai kesehatan kurang baik, maka akan memengaruhi anggota keluarga yang lain (Riska,2016). Orang tua memiliki peran yang penting dalam masa pertumbuhan anak, sekaligus dalam proses pencegahan dan penanggulangan penyakit ISPA. Ada macam-macam peran yang dilakukan orang tua seperti: peran sebagai penyedia, perawatan anak, sosialisasi anak, peran pendidikan, dan peran afektif, peran orang tua yang dimaksud disini adalah peran orang tua dalam perawatan anak dengan penyakit ISPA. Peran yang dilakukan orang tua bisa berupa apa saja yang menyangkut tentang kesehatan anak, seperti memberi obat, memperhatikan kebersihan diri anak.

Sebagian besar partisipan mengatakan memahami mengenai cara penanganan terhadap anggota keluarga yang menderita penyakit ISPA. Keluarga memeriksakan penderita ke tempat pengobatan untuk mendapatkan pengobatan. Partisipan mengatakan RS adalah dengan cara-cara tradisonal, partisipan mengatakan sering menggosokan minyak kayu putih, dan membawa anak untuk di bawa ke tukang urut. Penanganan dengan menggosokan minyak kayu putih sudah menjadi kebiasaan dari dulu karena dipercaya ketika anak setelah diberikan minyak kayu putih anak menjadi lebih nyaman ketika beristirahat di malam hari.

Menurut penelitian yang dilakukan oleh zulfa (2017) minyak kayu putih diproduksi dari daun tumbuhan Melaleuca leucadendra dengan kandungan terbesarnya adalah eucalyptol (cineole). Hasil penelitian tentang khasiat cineole menjelaskan cineol memberi efek mukolitik (mengencerkan dahak) bronchodilating (melegakan pernafasan), anti inflamasi. Menurut Dornish dkk dalam Zulnely (2015) minyak atsiri eucalyptus bisa digunakan untuk pengobatan herbal yang bermanfaat untuk mengobati rasa sesak di dada karena pilek atau asma dengan cara mengoleskan pada dada untuk melonggarkan dada yang terasa sesak. Mengobati sinus dengan minyak 
atsiri eucalyptus dengan menghirup uap udara hangat yang sebelumnya telah diteteskan beberapa tetes minyak atsiri eucalyptus ke dalamnya. Nadjib dkk (2014) dalam penelitiannya menyebutkan terdapat bukti yang menunjukkan bahwa uap minyak esensial dari Eucalyptus globulus efektif sebagai antibakteri dan layak dipertimbangkan penggunaannya dalam pengobatan atau pencegahan pasien dengan infeksi saluran pernapasan di rumah sakit.

Penggunaan minyak atsiri, salah satunya eucalyptus dengan metode inhalasi juga dilakukan dalam sebuah uji klinik dengan metode randomized double-blind, placebo-controlled pada obat semprot (spray) menggunakan lima minyak atsiri (Eucalyptus citriodora, Eucalyptus globulus, Mentha piperita, Origanum syriacum, and Rosmarinus officinalis) dilakukan pada pasien dengan masalah infeksi saluran pernafasan atas di enam klinik di Israel. Aromatic spray atau placebo digunakan sebanyak lima kali sehari selama tiga hari dengan dosis empat semprotan setiap kalinya yang diarahkan pada bagian belakang tenggorokan. Evaluasi terhadap gejala menunjukkan bahwa aromatic spray lebih efektif mengurangi gejala dibandingkan dengan plasebo (Julia, 2016).

Menurut Amir dan Hanafiah (2009) menyatakan bahwa tradisi adalah sesuatu yang identik dengan adat istiadat, kebiasaan kuno, sistem kepercayaan yang memengaruhi sikap dan pengetahuan mereka tentang sakit dan upaya penyembuhannya. Pada masyarakat pedesaan khususnya, pengobatan tradisional ini masih menduduki tempat teratas dibanding dengan pengobatan-pengobatan yang lain. Adapun keluarga mencari pengobatan sendiri sebelum keluarga mengantar anak yang menderita ISPA dibawa ke RS atau puskesmas karena pengalaman atau informasi yang didapat dari keluarga terdekat ataupun tetangga-tetangga sebelah rumah, selain itu pengobatan dengan cara tradisonal juga tidak memiliki efek samping dan biaya yang dikeluarkan juga tidak banyak, partisipan juga mengatakan bahwa biaya yang dikeluarkan untuk ke RS juga lumayan besar, dan juga rata-rata hampir sebagian besar partisipan tidak menggunakan asuransi kesehatan seperti BPJS. Namun keluarga akan tetap membawa anak ke Rumah sakit 
tetapi ketika penanganan awal dengan menggunakan cara-cara tradisional belum berhasil mengatasi penyakit, keluarga baru membawa anak untuk diperiksa di puskesmas, dokter praktik atau Rumah Sakit untuk mendapatkan pengobatan lebih lanjut di Rumah sakit, tetapi hal ini biasa dilakukan ketika anak sudah parah barulah dibawa ke tenaga kesehatan.

Selain membawa ke RS, di rumah keluarga juga memberikan beberapa perlakuan khusus kepada anak dengan penyakit ISPA, seperti memberikan obat dari dokter, menggosokan minyak kayu putih, menjaga kebersihan diri anak, dan lingkungan sekitar tempat tinggal, dengan harapan agar anak cepat sembuh dan dapat beraktifitas seperti anak-anak yang lain.

\section{Pencegahan Penyakit ISPA}

Pencegahan penyakit ISPA ini tidak terlepas dari peran orang tua yang sebenarnya harus mengetahui cara-cara pencegahan ISPA. Partisipan mengatakan bahwa partisipan juga tidak tahu bagaimana agar tidak terjadi penularan kepada anggota keluarga yang lain, partisipan hanya membatasi anaknya dari anggota keluarga yang lain agar tidak terjadi penularan.
Cara penularan utama sebagian besar ISPA adalah melalui droplet yang keluar dari hidung dan mulut penderita, tetapi penularan melalui kontak (termasuk kontaminasi tangan) dan aerosol pernapasan yang infeksius dalam jarak dekat. Menurut penelitian yang dilakukan oleh Siti Sundari dkk (2014), informasi mengenai ISPA masih kurang. Perilaku atau kebiasaan tidak sehat yang biasa dilakukan ibu tanpa disadari yang memiliki resiko terjadinya ISPA pada Balita dimulai dari yang paling dominan meliputi kebiasaan ibu tidak menutup hidung dan mulut ketika batuk, tidak menjauhkan anak dari orang yang sedang sakit infeksi saluran pernapasan akut, tidak segera mencuci tangan dengan sabun apabila tangan terkena cairan hidung dan mulut ketika batuk, tidak menjauhkan Balita sakit dari anggota keluarga lainnya, tidak membawa Balita untuk diimunisasi lengkap, tidak selalu menyediakan buah dan sayur dalam menu makanan sehari-hari (Ananditha, A. C. 2017)..

Banyak hal bisa dilakukan keluarga untuk mencegah agar tidak terjadi penularan pada anggota keluarga yang lain, bisa dengan cara menjaga kebersihan diri anak, kebersihan 
lingkungan, mengajarkan anak untuk selalu mencuci tangan, bukan hanya dengan membatasi aktifitas anak dengan keluarga lain saja. Mencuci tangan terbukti dapat mencegah penyakit diare dan ISPA (Infeksi Saluran Pernafasan Atas) yang menjadi penyebab utama kematian pada anakanak. (I Gusti, 2015). Menurut penelitian yang dilakukan oleh Intan (2014). Pencegahan bisa dilakukan dengan: Menjaga keadaan gizi agar tetap baik, imunisasi lengkap, Menjaga Kebersihan Perorangan dan Lingkungan, mencegah anak berhubungan langsung dengan anak penderita ISPA, pengobatan segera.

\section{Kesimpulan}

Pengetahuan partisipan tentang penyakit ISPA pada balita bahwa penyakit ISPA adalah penyakit batuk, flu, dan demam biasa, yang disebabkan karena kondisi cuaca yang sering berganti-ganti. Keluarga berperan sangat penting dalam proses pencegahan dan penanggulangan penyakit. Pengobatan tradisional merupakan pengobatan yang pertama kali dilakukan partisipan bila ada balitanya yang tiba-tiba sakit, dengan cara menggosokan minyak kayu putih, ataupun dibawa ke tukang urut. Jika pengobatan tradisional tidak membuahkan hasil barulah keluarga membawa balita berobat ke RS untuk mendapatkan obat dari tenaga kesehatan. Selain itu, saat di rumah keluarga memberikan beberapa perlakuan khusus kepada anak dengan penyakit ISPA yaitu menggosokan minyak kayu putih, menjaga kebersihan diri anak, dan lingkungan sekitar tempat tinggal, dengan harapan agar anak cepat sembuh dan dapat beraktifitas seperti anak-anak yang lain.

\section{Daftar Pustaka}

Aries W Estherina Nawangsari P. Pengetahuan Ibu Tentang Pencegahan Ispa Menurunkan Kejadian Ispa Pada

Balita.2015;8(2):107-116

Ananditha, A. C. (2017). Pengalaman Ibu Tentang Gaya Hidup Yang Menyebabkan Anak Beresiko Obesitas. Jurnal Keperawatan Muhammadiyah, 2(2).

Ali,Z.Pengantar keperawatan keluarga.jakarta:EGC.2010 
Amir \& Hanafiah, Jusuf. Etika Kedokteran Dan Hukum Kesehatan Edisi 4.Jakarta:EGC.2009

Cipto R, Siti A, Mariyam, Peran Keluarga Prasejahtera Dengan Upaya Pencegahan Infeksi Saluran Pernapasan Akut (ISPA) Pada Balita

Di Desa Depok Kecamatan

Kandeman Kabupaten Batang.

Oktober 2015;8(2):149-160

Eva Supriatin. Hubungan Faktor-

Faktor Dengan Kejadian ISPA pada Balita Di Puskesmas X Kota Bandung. Jurnal Keperawatan Indonesia 2013;1(1):39-46

Florentina Dian, Lidwina Triastuti, Monica Septianingsih. Peran Orang Tua Dalam Melakukan Pencegahan ISPA Pada Anak PrasekolahDi Desa Dukun Kabupaten Magelang.2013

Intan Silviana. Hubungan Pengetahuan Ibu Tentang Penyakit ISPA Dengan Perilaku Pencegahan ISPA Pada Balita Di PHPT Muara Angke JAKARTA

UTARA.2014;11(3):402-411

IGK Wijaya, Herwanti Bahar. Hubungan Kebiasaan Merokok, Imunisai Dengan Kejadian Penyakit
Pneumona Pada Balita Di Puskesmas Pabuaran Tumpeng Kota Tangerang.2014;11(3):375-385

I Gusti Made Geria Jelantik, I Gusti Ayu Rai Astarini.Hubungan Pengetahuan, Sikap Ibu Dan Ketersediaan Sarana Dengan Kebiasaan Cuci Tangan Pakai Sabun Untuk Mencegah Diare Dan ISPA Pada Ibu Rumah Tangga Di Kelurahan Ampenan Tengah Kota Mataram.2015;9(1):48-51

Julia B, Jane Buckle, editors. Respiratory care. Clinical aromatherapy (Third Edition). London: Churchill Livingstone;2016.p. 353-72.

Nadjib BM, Amine FM, Abdelkrim K, Fairouz S, Maamar M. Liquid and vapour phase antibacterial activity of eucalyptus globulus essential oil susceptibility of selected respiratory tract pathogens. American Journal of Infectious Disease. 2014;10(3):10517

Notoatmodjo,S. 2010. Ilmu Promosi Kesehatan. Rineka Cipta:Jakarta

Profil Kesehatan Provinsi Maluku. Dinas Kesehatan Provinsi Maluku. 
tahun 2014. diakses tanggal 26 January 2017

Profil Kesehatan Kota Ambon. Dinas Kesehatan Kota Ambon. Tahun 2014. diakses tanggal 26 January 2017

Paramitha A, Amatus Y, Abram Babakal. Hubungan Tingkat Pendidikan Dan Pengetahuan Ibu Tentang ISPA Dengan Kemampuan Ibu Merawat Balita ISPA Pada Balita Di Puskesmas Bahu Kota Manado.2013;1(1)

Riset Kesehatan Dasar. Badan Penelitian Dan Pengembangan

Kesehatan, Kementrian Kesehatan RI.2013

Riska W, Amatus Ismianto, Michael Karundeng. Hubungan Peran Orang Tua Dalam Pencegahan ISPA Dengan Kekambuhan ISPA Pada Balita Di Puskesmas Bilalang Kota Kotamobagu.2016:4(1)

Stela Olivya, Joost L, Peeki Rondonuwu. Hubungan Tingkat Pengetahuan Orang Tua Dengan Pencegahan Infeksi Saluran Pernapasan Akut (ISPA) Pada Anak Usia Balita Di Wilayah Kerja.
Puskesmas Tuminting Kota Manado.2016;3(2):75-81

Siti Sundari, Pratiwi, Khairudin. Perilaku Tidak Sehat Ibu yang Menjadi Faktor Resiko Terjadinya ISPA Pneumonia pada Balita. 2014;2(3):141-147

WHO. Pencegahan dan pengendalian infeksi saluran pernapasan akut (ISPA) yang cenderung menjadi epidemi dan pandemi di fasilitas pelayanan kesehatan. jenewa:WHO 2007.

Zulfa Auliyati Agustina, Suharmiati. Pemanfaatan Minyak Kayu Putih (Melaleuca leucadendra Linn) sebagai Alternatif Pencegahan ISPA: Studi Etnografi di Pulau Buru. Jurnal Kefarmasian Indonesia 2017;7(2):120-126

Zulnely, Gusmailina, Evi kusmiati. Prospek Eucaliptus citriodora sebagai minyak atsiri potensial. 2015;1(1):120-126 